\title{
Short Communication: Absorption of Protein and Immunoglobulin G in Calves Fed a Colostrum Replacer ${ }^{1}$
}

\author{
G. W. Smith ${ }^{2}$ and D. M. Foster \\ Department of Population Health and Pathobiology, College of Veterinary Medicine, North Carolina State University, Raleigh 27606
}

\begin{abstract}
A well-managed colostrum program on farms is the most important step in reducing disease in neonatal calves. In the last few years, colostrum replacers have increased in popularity and are designed to be an alternative to colostrum on farms that have poor colostrum quality, limited colostrum reserves, or to break the cycle of transmission for certain infectious diseases. However, it is important to make sure these products are effective and are capable of providing adequate serum immunoglobulin concentrations. The objective of this study was to evaluate the efficacy of a commercially available colostrum replacer product in dairy calves. Holstein calves from a single dairy were randomly assigned to 1 of 3 groups at birth. Group $1(n=21)$ calves were given 4 quarts of colostrum via esophageal feeder within $3 \mathrm{~h}$ of birth and served as the control group for this study. Group $2(\mathrm{n}=21)$ received 2 packages of a colostrum replacer product, and group $3(n=21)$ received 3 packages of the colostrum replacer product within $3 \mathrm{~h}$ of birth. Blood samples from all calves were collected $24 \mathrm{~h}$ after colostrum administration and analyzed for serum total protein and IgG concentrations. Calves fed fresh colostrum had significantly higher serum total protein levels and IgG concentrations compared with calves fed the colostrum replacer product. Calves fed the colostrum replacer also had a significantly higher percentage of calves with failure of passive transfer (serum IgG $<1,000 \mathrm{mg} / \mathrm{dL}$ ). The colostrum replacer product evaluated in this study failed to routinely provide adequate IgG concentrations when fed according to label directions.
\end{abstract}

Key words: passive transfer, calf diarrhea, colostrum, radial immunodiffusion

Ingestion and absorption of colostral immunoglobulins are 2 of the most important aspects in the preven-

Received October 17, 2006.

Accepted December 20, 2006.

${ }^{1}$ This project was supported in part by a grant from Accelerated Genetics.

${ }^{2}$ Corresponding author: Geoffrey_Smith@ncsu.edu tion of neonatal calf disease because calves acquire virtually no immunoglobulins in utero. In spite of this knowledge, failure of transfer of passive immunity (FTPI) remains extremely common in the US dairy industry (Weaver et al., 2000). Calves with inadequate immunoglobulin concentrations have reduced growth rates, increased risk of disease and death, increased risk of being culled, and decreased milk production in their first lactation (DeNise et al., 1989; Tyler et al., 1998; Tyler et al., 1999; Virtala et al., 1999; Faber et al., 2005). Consequently, FTPI has profound effects on the survival and productivity of dairy heifers.

The transfer of immunity from colostrum ingestion is generally considered to be adequate if serum IgG concentrations are above $1,000 \mathrm{mg} / \mathrm{dL}$ (McGuirk and Collins, 2004). Several steps are critical to ensuring adequate colostral immunity. These include administering a large quantity of good quality colostrum to provide adequate immunoglobulin mass within the first few hours of life. General recommendations include feeding $4 \mathrm{~L}$ of colostrum with greater than $50 \mathrm{~g} / \mathrm{L}$ of IgG and less than $100,000 \mathrm{cfu} / \mathrm{mL}$ of bacteria within the first 6 to $8 \mathrm{~h}$ of life (McGuirk and Collins, 2004). In cases of poor colostrum quality, excessive bacterial contamination, or little frozen reserve of colostrum, dairy managers often attempt to use colostrum replacers or supplements to avoid FTPI in calves. As a part of biosecurity programs, colostrum replacers may also be used to prevent transmission of diseases including Salmonella, Mycobacterium avium ssp. paratuberculosis, bovine leukemia virus, and bovine viral diarrhea virus.

Despite their wide use, peer-reviewed studies evaluating these products are lacking. Although a few serumbased colostrum replacers (Quigley et al., 2002; Poulsen et al., 2003; Jones et al., 2004) and one colostrum-based replacer product (Foster et al., 2006) have been effective, many other products have failed to routinely provide the necessary $1,000 \mathrm{mg} / \mathrm{dL}$ of serum IgG to dairy calves (Zaremba et al., 1993; Garry et al., 1996; Mee et al., 1996; Holloway et al., 2002; Foster et al., 2006) when fed according to label directions. The purpose of this study was to evaluate commercially available 
colostrum-based replacer products as a sole source of serum IgG for dairy calves compared with natural bovine colostrum on a typical dairy in the southeastern United States.

This study was approved by our institutional committee on the care and use of laboratory animals. Sixtythree Holstein bull calves from a 1,400-cow dairy in western North Carolina were randomly assigned to 1 of 3 treatment groups at birth.

Calves were separated from the dam following an observed parturition and were not allowed to nurse. Calves used in the study had to weigh at least $32 \mathrm{~kg}$ (70 lb), and all animals born as twins were excluded. After birth, calves were randomly allocated to 1 of 3 groups. Calves in group $1(\mathrm{n}=21)$ received 4 quarts of colostrum within $3 \mathrm{~h}$ of birth via an esophageal feeder. The dam of each calf was milked out completely immediately after parturition, and each calf was given first milking colostrum from only its dam. Calves in group $2(n=21)$ received 2 packages of a colostrum replacer (First Day Formula, Accelerated Genetics, Westby, WI) equivalent to $100 \mathrm{~g}$ of $\mathrm{IgG}$ (or $41 \mathrm{~g}$ of IgG per liter as fed). Calves in group $3(\mathrm{n}=21)$ were fed 3 packages of the same colostrum replacer equivalent to $150 \mathrm{~g}$ of IgG (41 g/L as fed). All calves in each group were fed with an esophageal feeder within $3 \mathrm{~h}$ of birth. Colostrum replacers were mixed individually for each calf according to label directions.

A blood sample was collected from the jugular vein of each calf $24 \mathrm{~h}$ after colostrum or colostrum replacer administration. The samples were collected into plain glass tubes and allowed to clot. The serum was removed and stored at $-4^{\circ} \mathrm{C}$ until analysis. A serum sample from each calf was sent to an independent laboratory (Prairie Diagnostic Services, Saskatoon, Saskatchewan, Canada) that was blinded to the treatment group of the sample. Protein concentrations in serum samples were determined using a digital temperature compensating refractometer (model 300027, SPER Scientific Ltd., Scottsdale, AZ). The refractometer prism was cleaned, and the machine calibrated with distilled water between each sample.

Radial immunodiffusion was performed on all serum samples using a bovine IgG species reference serum that was obtained from USDA Center for Veterinary Biologics. The IgG concentrations were established by turbidimetric assay (Etzel et al., 1997) and had a reported IgG value of $3,204 \mathrm{mg} / \mathrm{dL}$. Following the instructions of the USDA Center for Veterinary Biologics, the serum was prediluted one-third in PBS prior to testing. The radial immunodiffusion assay uses an antiserum that is both heavy and light chain reactive and measures $\mathrm{IgG}_{1}$ and $\mathrm{IgG}_{2}$. The assay has been validated for use in calves (Chelack et al., 1993).
Data are presented as mean \pm SD. Mean $\operatorname{IgG}$ and total protein concentrations for both groups receiving colostrum replacer were compared with the group fed bovine colostrum using unpaired $t$-tests after conducting an overall 1-way ANOVA, and means were considered significantly different at $P<0.05$. The proportion of calves in each group that had an IgG concentration greater than or equal to $1,000 \mathrm{mg} / \mathrm{dL}$ was also compared with the control group using Fisher's exact test.

Mean IgG and total protein concentrations in calves from group 1 were significantly higher than the other 2 groups (Table 1). The proportion of calves with adequate colostral immunity (defined as serum IgG $\geq 1,000 \mathrm{mg} /$ $\mathrm{dL}$ ) in groups 2 and 3 were significantly lower compared with group 1 calves.

In this study, calves fed fresh colostrum had markedly higher serum IgG and total protein concentrations as compared with calves fed the colostrum replacer product. Calves in groups 2 and 3 also had a significantly higher percentage of FTPI, and therefore this product appears to be unacceptable as a colostrum replacer.

The colostral immunoglobulin requirement for calves is estimated to be about 80 to $100 \mathrm{~g}$ (Petrie, 1984). Therefore it has commonly been assumed that colostrum- or serum-based products containing over $100 \mathrm{~g}$ of IgG would be effective colostrum replacers for calves. However, simply measuring the mass of IgG provided by a replacer product is an inadequate predictor of its efficacy. For example, a previous study fed groups of calves 3 different commercially available colostrum replacer products providing an IgG mass of 107, 126, and $156 \mathrm{~g}$, respectively. All 3 groups in this study had IgG concentrations lower than what was observed in calves fed fresh colostrum, and the percentage of calves with failure of passive transfer was 100\% in all colostrum replacer groups (Garry et al., 1996). In another study calves receiving a colostrum replacer product containing $90 \mathrm{~g}$ of IgG had a serum IgG concentration of $643 \mathrm{mg} / \mathrm{dL}$, and $75 \%$ of calves had failure of passive transfer (Holloway et al., 2002). In a third study calves fed a product containing $100 \mathrm{~g}$ of IgG had mean serum IgG concentrations of $700 \mathrm{mg} / \mathrm{dL}$, and $90 \%$ of calves had failure of passive transfer (Foster et al., 2006).

In contrast, studies using other serum-based colostrum replacer products providing IgG concentrations from 125 to $175 \mathrm{~g}$ have resulted in successful transfer of immunoglobulins to calves (Quigley et al., 2002; Poulsen et al., 2003). In one report, 289 calves from 8 different dairy farms were divided into 2 groups and fed colostrum or a colostrum-replacer product containing $125 \mathrm{~g}$ of IgG. There was no difference between groups in the number of calves that achieved adequate transfer of passive transfer (serum IgG concentrations 
Table 1. Mean \pm SD values for serum IgG and total protein concentrations and the percentage of animals that had failure of transfer of passive immunity (FTPI) in calves fed colostrum or a colostrum replacer

\begin{tabular}{lccc}
\hline Group & $\begin{array}{c}\text { Serum IgG } \\
(\mathrm{mg} / \mathrm{dL})\end{array}$ & $\begin{array}{c}\text { Total protein } \\
(\mathrm{g} / \mathrm{dL})\end{array}$ & $\begin{array}{c}\mathrm{FTPI}^{1} \\
(\%)\end{array}$ \\
\hline Group 1 (colostrum) & $1,760 \pm 560$ & $5.4 \pm 0.5$ & $5(1 / 21)$ \\
Group 2 (2 bags of colostrum replacer) & $750 \pm 130^{*}$ & $4.4 \pm 0.3^{*}$ & $95(20 / 21)^{*}$ \\
Group 3 (3 bags of colostrum replacer) & $910 \pm 550^{*}$ & $4.7 \pm 0.5^{*}$ & $76(16 / 21)^{*}$ \\
\hline
\end{tabular}

*Indicates values were significantly different compared with group 1 .

${ }^{1}$ Failure of transfer of passive immunity was defined as a serum IgG concentration less than $1,000 \mathrm{mg} /$ dL.

$>1,000 \mathrm{mg} / \mathrm{dL}$ ) or health scores (based on fecal consistency, appetite, and attitude monitoring) between the 2 groups (Poulsen et al., 2003). In another study calves fed a colostrum-replacer product containing $175 \mathrm{~g}$ of IgG had a mean serum IgG concentration of $1,360 \mathrm{mg} /$ $\mathrm{dL}$ at $24 \mathrm{~h}$ after feeding (Quigley et al., 2002). A third study fed a colostrum-based replacer product containing $100 \mathrm{~g}$ of IgG. Calves fed this product had a mean serum IgG concentration of $1,160 \mathrm{mg} / \mathrm{dL}$ and there was no difference in the percentage of calves with adequate transfer of passive immunity as compared with a group fed fresh colostrum (Foster et al., 2006). The calves in groups 2 and 3 of the study reported here received approximately 100 and $150 \mathrm{~g}$ of $\mathrm{IgG}$, respectively, yet did not have adequate serum IgG concentrations. Thus there appears to be a number of factors that control the efficiency of IgG absorption between different colostrum-replacer products. Simply examining the mass of IgG provided by the colostrum replacer is not an adequate measure of product efficacy.

Various studies have analyzed different factors including source of IgG, method of IgG fractionation, amount and type of non-IgG protein, and presence of fat and lactose and their effects on efficiency of IgG absorption in colostrum replacers and supplements (Mee et al., 1996; Arthington et al., 2000; Davenport et al., 2000; Quigley et al., 2001). For example, large amounts of casein in colostrum supplements have been shown to significantly reduce the efficiency of IgG absorption (Davenport et al., 2000). Furthermore, research has shown that addition of some colostrum supplements reduces the absorption of IgG from natural colostrum (Stott et al., 1979; Hopkins and Quigley, 1997; Morin et al., 1997). Therefore, each colostrum replacer and supplement product should be properly evaluated for efficacy prior to use.

Mean serum IgG concentrations $(1,760 \mathrm{mg} / \mathrm{dL})$ for group 1 calves in this study are similar to what has been reported in other studies for Holstein calves receiving 4 $\mathrm{L}$ of colostrum but are lower than reported in another study conducted on this same farm (Foster et al., 2006). Several previous studies have reported values ranging from 1,200 to $1,900 \mathrm{mg} / \mathrm{dL}$ in Holstein calves following $4 \mathrm{~L}$ of colostrum immediately after birth, or $2 \mathrm{~L}$ after birth followed by $2 \mathrm{~L}$ at $12 \mathrm{~h}$ of age (Adams et al., 1985; Tyler et al., 1988; Hopkins and Quigley, 1997). However, in another recent study, calves receiving $4 \mathrm{~L}$ of colostrum had a mean serum IgG concentration of $2,720 \mathrm{mg} / \mathrm{dL}$ (Foster et al., 2006). The reason for the difference in serum IgG between this and the present study are not known; however, the exact same colostrum collection and administration protocol was followed in both projects. Mean colostral immunoglobulin concentrations in the initial study $(118 \pm 44 \mathrm{~g} / \mathrm{L})$ were substantially higher than what is expected for the Holstein breed, which was likely the reason for the high serum IgG concentration in the control calves from this study (Foster et al., 2006). Many factors can affect colostrum IgG including time between calving and colostrum collection, cow parity, and season. Unfortunately, data on IgG concentrations for the colostrum samples fed to calves in this trial are not available; however, we would anticipate they would have been lower than what was previously observed.

The results of this study demonstrated that the colostrum replacer product evaluated was not an effective colostrum replacer because few calves achieved serum IgG concentrations of greater than $1,000 \mathrm{mg} / \mathrm{dL}$. However, the product could perhaps be used a colostrum supplement when there is inadequate colostrum quality because there was some IgG transferred to the calves.

\section{REFERENCES}

Adams, G. D., L. J. Bush, J. L. Horner, and T. E. Staley. 1985. Two methods for administering colostrum to newborn calves. J. Dairy Sci. 68:773-775.

Arthington, J. D., M. B. Cattell, and J. F. Quigley. 2000. Effect of dietary IgG source (colostrum, serum, or milk-derived supplement) on the efficiency of Ig absorption in newborn Holstein calves. J. Dairy Sci. 83:1463-1467.

Chelack, B. J., P. S. Morley, and D. M. Haines. 1993. Evaluation of methods for dehydration of bovine colostrum for total replacement of normal colostrum in calves. Can. Vet. J. 34:407-412.

Davenport, D. F., J. D. Quigley, J. E. Martin, J. A. Holt, and J. D. Arthington. 2000. Addition of casein or whey protein to colostrum or a colostrum supplement product on absorption of IgG in neonatal calves. J. Dairy Sci. 83:2813-2819. 
DeNise, S. K., J. D. Robinson, G. H. Stott, and D. V. Armstrong. 1989. Effects of passive immunity on subsequent production in dairy heifers. J. Dairy Sci. 72:552-554.

Etzel, L. R., R. F. Strohbehn, and J. K. McVicker. 1997. Development of an automated turbidometric immunoassay for quantification of bovine serum immunoglobulin G. Am. J. Vet. Res. 58:1201-1205.

Faber, S. N., N. E. Faber, T. C. McCauley, and R. L. Ax. 2005. Effects of colostrum ingestion on lactational performance. Prof. Anim. Sci. 21:420-425.

Foster, D. M., G. W. Smith, T. R. Sanner, and G. V. Busso. 2006. Serum IgG and total protein concentrations in dairy calves fed two colostrum replacement products. J. Am. Vet. Med. Assoc. 229:1282-1285.

Garry, F. B., R. Adams, M. B. Cattell, and R. P. Dinsmore. 1996. Comparison of passive immunoglobulin transfer to dairy calves fed colostrum or commercially available colostral-supplement products. J. Am. Vet. Med. Assoc. 208:107-110.

Holloway, N. M., J. W. Tyler, J. Lakritz, S. L. Carlson, R. K. Tessman, and J. Holle. 2002. Serum immunoglobulin G concentrations in calves fed fresh colostrum or a colostrum supplement. J. Vet. Intern. Med. 16:187-191.

Hopkins, B. A., and J. D. Quigley. 1997. Effects of method of colostrum feeding and colostrum supplementation on concentrations of immunoglobulin G in the serum of neonatal calves. J. Dairy Sci. 80:979-983.

Jones, C. M., R. E. James, J. D. Quigley, and M. L. McGilliard. 2004. Influence of pooled colostrum or colostrum replacement on IgG and evaluation of animal plasma in milk replacer. J. Dairy Sci. 87:1806-1814.

McGuirk, S. M., and M. Collins. 2004. Managing the production, storage, and delivery of colostrum. Vet. Clin. North Am. Food Anim. Pract. 20:593-603.

Mee, J. F., K. J. O’Farrell, P. Reitsma, and R. Mehra. 1996. Effect of a whey protein concentrate used as a colostrum substitute or supplement on calf immunity, weight gain, and health. J. Dairy Sci. 79:886-889.
Morin, D. E., G. C. McCoy, and W. L. Hurley. 1997. Effects of quality, quantity, and timing of colostrum feeding and addition of a dried colostrum supplement on immunoglobulin G absorption in Holstein bull calves. J. Dairy Sci. 80:747-753.

Petrie, L. 1984. Maximizing the absorption of colostral immunoglobulins in the newborn dairy calf. Vet. Rec. 114:157-163.

Poulsen, K. P., V. Eggleston, M. T. Collins, and S. M. McGuirk. 2003. The efficacy of a colostrum replacement product used in dairy calves. J. Vet. Intern. Med. 17:391 (Abstr. 50).

Quigley, J. D., C. J. Kost, and T. M. Wolfe. 2002. Absorption of protein and IgG in calves fed a colostrum supplement or replacer. J. Dairy Sci. 85:1243-1248.

Quigley, J. D., R. E. Strohbehn, C. J. Kost, and M. M. O'Brien. 2001. Formulation of colostrum supplements, colostrum replacers, and acquisition of passive immunity in dairy calves. J. Dairy Sci. 84:2059-2065.

Stott, G. H., D. B. Marx, B. E. Menefee, and G. T. Nightengale. 1979. Colostral immunoglobulin transfer in calves. III. Amount of absorption. J. Dairy Sci. 62:1902-1907.

Tyler, J. W., D. D. Hancock, J. Thorne, C. C. Gay, and J. M. Gay. 1999. A model partitioning the risk of mortality associated with inadequate passive transfer in dairy calves. J. Vet. Intern. Med. 13:335-337.

Tyler, J. W., D. D. Hancock, S. E. Wiksie, S. L. Holler, J. M. Gay, and C. C. Gay. 1998. Use of serum protein concentration to predict mortality in mixed-source dairy replacement heifers. J. Vet. Intern. Med. 12:79-83.

Virtala, A. M. K., Y. T. Gröhn, G. D. Mechor, and H. N. Erb. 1999 The effect of maternally derived immunoglobulin $\mathrm{G}$ on the risk of respiratory disease in heifers during the first 3 months of life. Prev. Vet. Med. 39:25-37.

Weaver, D. M., J. W. Tyler, D. C. Van Metre, D. E. Hostetler, and G. M. Barrington. 2000. Passive transfer of colostral immunoglobulins to calves. J. Vet. Intern. Med. 14:569-577.

Zaremba, W., W. M. Guterbock, and C. A. Holmberg. 1993. Efficacy of a dried colostrum powder in the prevention of disease in neonatal Holstein calves. J. Dairy Sci. 76:831-836. 